\title{
Evaluation of fat mass and its correlation with abnormal blood pressure in children and adolescents
}

\author{
IWONA PIROGOWICZ ${ }^{1, A, B, E, F}$, MACIEJ ORNAT 2,3, A-E, KRZYSZTOF PACHOŁEK 2, 3, A, B, D-F,

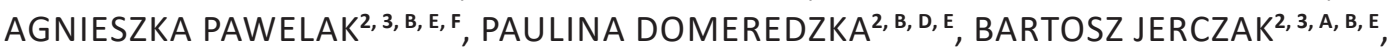 \\ ŁUKASZ GOJNY2, E
}

\author{
${ }^{1}$ Department and Clinic of Geriatrics, Wroclaw Medical University, Poland \\ ${ }^{2}$ Student Scientific Organization for Health Promotion and Disease Prevention at the Department and Clinic \\ of Geriatrics, Wroclaw Medical University, Poland \\ ${ }^{3}$ Student Scientific Society of Geriatrics and Gerontology at the University and Clinical Department of Geriatrics, \\ Wroclaw Medical University, Poland
}

\author{
A - Study Design, B - Data Collection, C - Statistical Analysis, D - Data Interpretation, E - Manuscript Preparation, F - Literature \\ Search, G - Funds Collection
}

Summary Background. The problem of developmental obesity is growing in most countries of the world, reaching an epidemic. Excessive body weight in childhood results in a greater likelihood of obesity in adulthood, as well as causing endocrine, orthopedic, cardiological and psychogenic disorders. Overweight and obesity appear to be the most important causative factor. Objectives. The aim of the study was to estimate the usefulness of body composition analysis in predicting high blood pressure among children and adolescents and the correlation between the parameters of body mass and blood pressure (BP).

Material and methods. Children from the age of 8 to 15 with recurrent respiratory tract diseases were selected during a rehabilitation and wellness stay in CRR KRUS in Szklarska Poreba. Body composition analysis was performed using the Tanita MC-780MA analyzer, and blood pressure was measured with a dial gauge. The study was conducted between 2015 and 2016, creating a database of 325 results sets.

Results. Statistically significant correlations between systolic blood pressure, diastolic blood pressure, body weight and fat mass content were shown $(p<0.001)$. BMI and body fat content correlations were also statistically significant $(p<0.001)$.

Conclusions. There is a problem of under-diagnosis of hypertension in the pediatric population. Obesity and overweight are connected with abnormal BP and hypertension. The total content of fat mass correlates with abnormal BP and hypertension.

Key words: hypertension, overweight, body composition, pediatrics, respiratory tract diseases.

Pirogowicz I, Ornat M, Pachołek K, Pawelak A, Domeredzka P, Jerczak B, Gojny Ł. Evaluation of fat mass and its correlation with abnormal blood pressure in children and adolescents. Fam Med Prim Care Rev 2017; 19(3): 256-260, doi: https://doi.org/10.5114/ fmpcr.2017.69288

\section{Background}

Obesity - an excess accumulation of fat in the body - is invariably considered to be the most common defect in the physical development of children [1]. Despite numerous social campaigns and prevention programs aimed at combating obesity and promoting healthy lifestyles, obesity is growing in most parts of the world, reaching an epidemic [2]. According to figures published by WHO in 2015, the number of children under 5 years of age with overweight and obesity amounted to 42 million. In Poland, studies in two age groups showed obesity in 2.9$-3.6 \%$ of boys and $5.2-6.2 \%$ of girls aged $13-15$, as well as $7.2 \%$ of girls and $8.4 \%$ of boys of preschool age. Particularly worrying is the fact that a significant proportion of obesity among young children is measured in groups up to 3 years of age [3]

Excessive body weight in childhood results in a greater likelihood of adult obesity, as well as endocrine, orthopedic, cardiological and psychogenic disorders [4]. Furthermore, people with obesity and high BP are prone to develop metabolic syndromes [2]. In these patients, body composition measurement with the use of bioelectric impedance analysis (BIA) is recommended along with BMI. Body fat percentage is crucial, as it shows a positive correlation with systolic and diastolic hypertension [5]. The benefits of BIA include its decreasing costs, simplicity and a graphic presentation of results, which is easily understandable for patients.

In addition, obesity and overweight are considered as the main causes of primary hypertension (HT) in children. Too high blood pressure (BP) affects about $3-3.5 \%$ of the population under the age of 18. In recent years, the epidemiology of primary HT has increased. Overweight and obesity appear to be the most important causative factor. A reduction in muscle mass plays a significant role. This constitutes an obstacle to physical activity for children, which, in combination with healthy eating habits, is the most important non-pharmacological therapy for HT $[2,3]$. Besides this, rehabilitation care has a positive effect on decreasing BP [6].

We noticed a problem of insufficient recognition of hypertension among the pediatric population in our previous research [6], and this is why we decided to undertake a more detailed analysis of this issue.

\section{Objectives}

The aim of the study was to estimate the usefulness of body composition analysis in predicting high blood pressure among children and adolescents and the correlation between BMI, weight, fat mass and BP. 


\section{Material and methods}

Analysis of body composition and BP measurements were part of the medical care provided during the rehabilitation and wellness stay in CRR KRUS in Szklarska Poreba, Poland. This was organized for children from rural areas suffering from chronic respiratory tract illnesses. Body composition analysis, containing body weight, muscle mass and fat mass (FM) and body water, was performed using the Tanita MC-780MA body weight analyzer, while BP was measured using a dial gauge with the cuffs properly adjusted to the forearm's diameter. MAP was calculated on the basis of the formula: MAP $=\mathrm{DBP}+1 / 3(\mathrm{SBP}-\mathrm{DBP})$. All the children were examined in the morning before breakfast. The results were collected in 2015 and 2016 during two camps. The database was prepared using Microsoft Excel, while statistical analysis was performed using Statistica software provided by StatSoft Inc.

According to the data in the Fourth Report on the Diagnosis, Evaluation and Treatment of High Blood Pressure in Children and Adolescents, we defined normal $\mathrm{BP}\left(<90^{\text {th }}\right.$ percentile $)$, abnormal BP ( $\geq 90^{\text {th }}$ and $<95^{\text {th }}$ percentile) and hypertension ( $\geq 95^{\text {th }}$ percentile) [7]. To define overweight and obesity, we used weight and BMI. According to percentile charts published as a result of the OLAF project, we classified children as overweight ( $\geq 90^{\text {th }}$ percentile) and obese ( $\geq 97^{\text {th }}$ percentile) [3]. The OLAF project was a scientific description of BP, body weight, BMI and body height for Polish children between the age of 7-18 [8]. Using FM\% results from body composition analysis, we used another classification, where children having FM greater than the $85^{\text {th }}$ percentile were considered as overweight, and those greater than the $95^{\text {th }}$ percentile as obese [9].

Statistical analysis of the obtained results was done with Statisitca software (StatSoft Poland, version 12). Normal distribution was checked with the use of the Shapiro-Wilk test. The results were presented as medians with minimum and maximum values (range). The correlation between parameters was assessed with the Spearman's rank correlation coefficient. The statistical significance of differences between groups was assessed with the non-parametric Mann-Whitney $U$ Test. In all evaluated cases, statistically significant $p$-values were accepted at less than 0.05 .

\section{Results}

The characteristics of the analyzed group are presented in Table 1.

The weight and BMI percentiles in the examined group of children are higher in comparison with the percentile values for the nationwide population (shifts in the right distribution curve toward higher values). Percentile growth, in turn, is lower than that for the national population (Figure 1, 2).

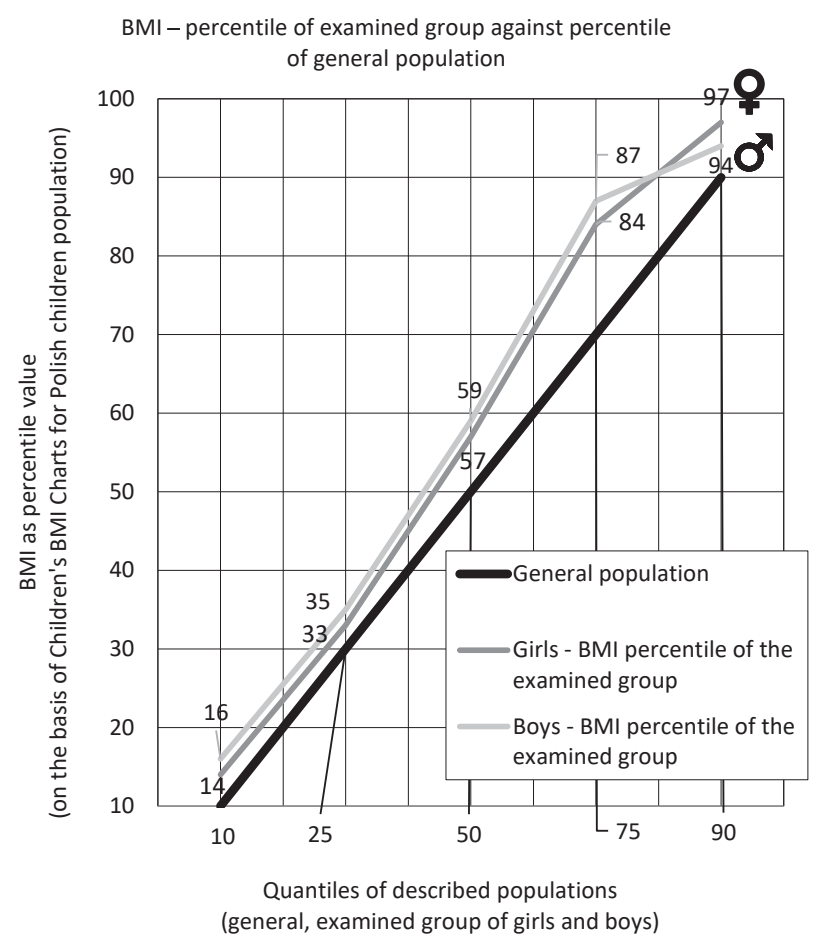

Figure 1. Distribution of BMI percentile values of the examined group against the general population (percentiles on the basis of project OLAF)

\begin{tabular}{|c|c|c|c|c|}
\hline \multicolumn{5}{|c|}{ Characteristics of the research group } \\
\hline \multicolumn{2}{|l|}{ Gender } & Girls & Boys & Summary \\
\hline \multicolumn{2}{|l|}{ Population } & 169 & 156 & 325 \\
\hline \multicolumn{2}{|l|}{ Age [years] } & $13(8-15)$ & $12(8-15)$ & $12(8-15)$ \\
\hline \multirow[t]{4}{*}{ Illness } & bronchial asthma & $29.6 \%$ & $43.6 \%$ & $36.3 \%$ \\
\hline & recurrent upper respiratory tract infections & $66.9 \%$ & $47.4 \%$ & $59.4 \%$ \\
\hline & atopic dermatitis & $1.1 \%$ & $0.6 \%$ & $0.9 \%$ \\
\hline & allergic rhinitis & $4.1 \%$ & $5.8 \%$ & $4.9 \%$ \\
\hline \multirow[t]{4}{*}{ Use of medicines } & inhaled glucocorticosteroids & $16.6 \%$ & $30.1 \%$ & $20.6 \%$ \\
\hline & $\beta$-mimetics (MDI) & $8.9 \%$ & $18.6 \%$ & $13.5 \%$ \\
\hline & antihistamines & $16 \%$ & $19.9 \%$ & $17.9 \%$ \\
\hline & montelucast & $7.7 \%$ & $19.2 \%$ & $13.2 \%$ \\
\hline \multicolumn{2}{|c|}{ Systolic blood pressure [mm Hg] } & $110(73-142)$ & $115(86-146)$ & $112(73-146)$ \\
\hline \multicolumn{2}{|c|}{ Diastolic blood pressure [mm Hg] } & $70(48-105)$ & $70(46-104)$ & $70(46-105)$ \\
\hline \multicolumn{2}{|c|}{ Mean arterial pressure $[\mathrm{mm} \mathrm{Hg}]$} & $84(60-115)$ & $85(60-118)$ & $84(60-118)$ \\
\hline \multicolumn{2}{|l|}{ Weight [kg] } & $47.5(18.9-103.9)$ & $46.5(19.8-90)$ & $46.9(18.9-103.9)$ \\
\hline \multicolumn{2}{|l|}{ Height $[\mathrm{cm}]$} & $156(115-175)$ & $153(115-190)$ & $156(115-190)$ \\
\hline \multicolumn{2}{|l|}{ BMI $\left[\mathrm{kg} / \mathrm{m}^{2}\right]$} & $19.4(13.5-38.6)$ & $19.2(13.5-33.2)$ & $19.3(13.5-38.6)$ \\
\hline \multicolumn{2}{|l|}{$\% F M[\%]$} & $25.5(16.9-45.6)$ & $20.4(10.6-44.4)$ & $23.6(10.6-45.6)$ \\
\hline \multicolumn{2}{|c|}{$\%$ of muscle mass [\%] } & $42.1(27.3-47.1)$ & $45(20.7-56.6)$ & $43.1(20.7-56.6)$ \\
\hline
\end{tabular}


Body weight - percentile of examined group against percentile of general population

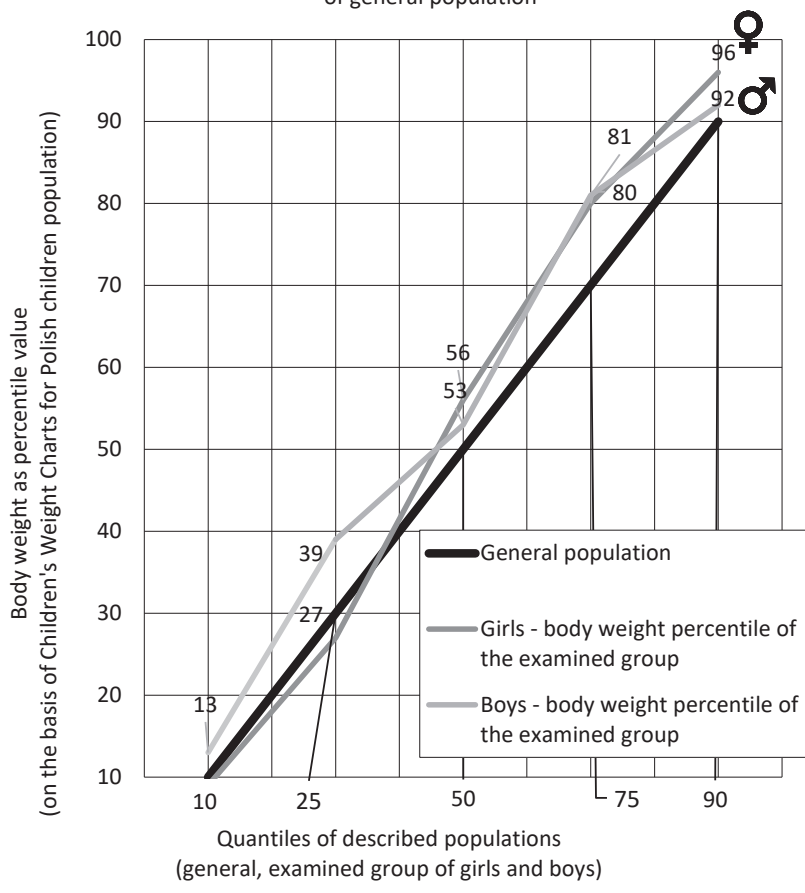

Figure 2. Distribution of body weight percentile values of the examined group against the general population (percentiles on the basis of project OLAF)

People with overweight or obesity (assessed by body weight, BMI and \%FM) had statistically significantly higher abnormal high $\mathrm{BP}$ and $\mathrm{HT}$ ( $>90^{\text {th }}$ percentile) compared to the normal weight group (chi-square test; $p<0.0001$ ) (Table 2). In addition, children with excessive \%FM and abnormally high BMI values had statistically significantly higher systolic, diastolic and mean BP (Figure 3-5).

There was no significant difference in SBP, DBP, MAP, body weight, $\mathrm{BMI}, \% \mathrm{FM}$ and muscle mass in asthmatic children compared to non-asthmatic children $(p>0.05)$. Similarly, there were no differences in the parameters analyzed, depending on the use of the following drugs: inhaled glucocortycoides (iGCS), $\beta$-mimetics (MDI), anti-histamines.

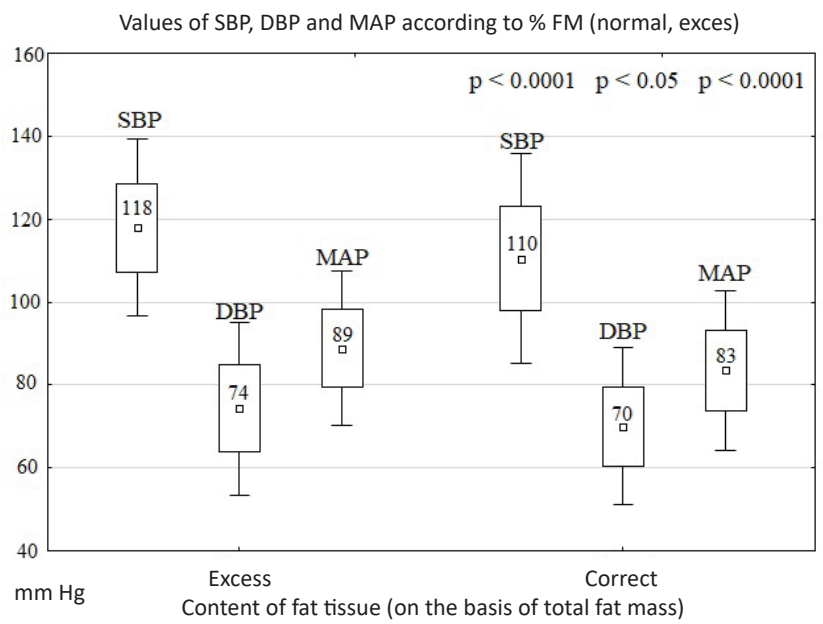

Figure 4. Values of SBP, DBP and MAP in groups of correct and excess content of fat tissue among the examined group of children ( $p$-values are situated on the graphs above the proper diagrams, Mann-Whitney U Test)

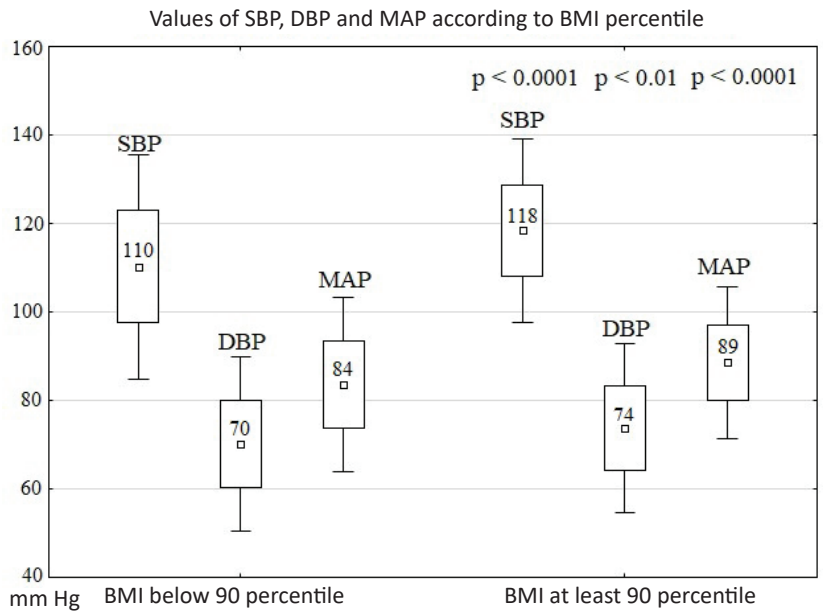

Figure 5. Values of SBP, DBP and MAP in the groups of examined children with $\mathrm{BMI}$ below $90^{\text {th }}$ percentile and at least $90^{\text {th }}$ percentile ( $p$-values are situated on the graphs above the proper diagrams, Mann-Whitney U Test)

Frequency of high normal blood pressure and hypertension

$\square 90-95$ percentile $\quad \square \geq 95$ percentile

$47 \%$

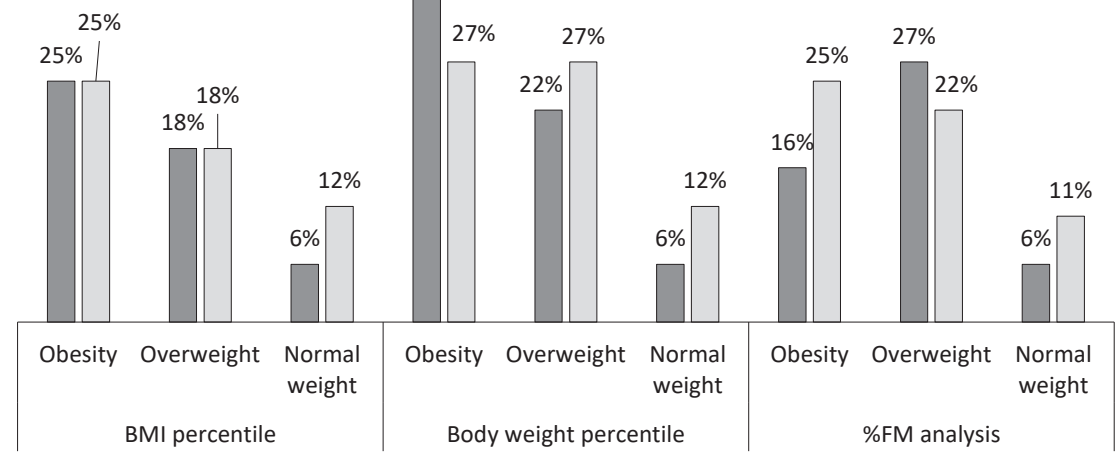

Figure 3. Incidence of abnormal BP (range $90^{\text {th }}-95^{\text {th }}$ percentile) and hypertension ( $\geq 95^{\text {th }}$ percentile), depending on nutritional status (obesity, overweight, normal body weight), estimated based on three parameters: BMI, body weight and content \%FM (percentiles on the basis of project OLAF) 


\begin{tabular}{|c|c|c|c|}
\hline \multicolumn{3}{|l|}{ Chi-square test } & $p$ \\
\hline \multirow[t]{3}{*}{ More often occurs: } & \multicolumn{2}{|c|}{ BP above $90^{\text {th }}$ percentile in people with excessive BMI compared to normal BMI } & $<0.0001$ \\
\hline & BP above $90^{\text {th }}$ percentile & \multirow{2}{*}{$\begin{array}{l}\text { in people with excess \%FM } \\
\text { compared to normal \%FM }\end{array}$} & $<0.0001$ \\
\hline & HT & & $<0.01$ \\
\hline
\end{tabular}

\begin{tabular}{|c|c|c|c|c|c|c|c|}
\hline Variable & SBP & DBP & Body mass & BMI & Muscle mass (\%) & $\%$ FM & Group \\
\hline SBP & - & 0.58 & 0.30 & 0.29 & -0.30 & 0.33 & \multirow[t]{6}{*}{ girls } \\
\hline DBP & 0.59 & - & 0.13 & 0.11 & -0.09 & 0.12 & \\
\hline Body mass & 0.43 & 0.27 & - & 0.91 & -0.74 & 0.78 & \\
\hline BMI & 0.37 & 0.26 & 0.91 & - & -0.80 & 0.81 & \\
\hline Muscle mass (\%) & -0.21 & -0.29 & -0.60 & -0.72 & - & -0.98 & \\
\hline$\% \mathrm{FM}$ & 0.28 & 0.28 & 0.68 & 0.80 & -0.93 & - & \\
\hline Group & \multicolumn{6}{|l|}{ boys } & - \\
\hline
\end{tabular}

There was no correlation between the number of diagnoses and the SBP, DBP, MAP, body mass, growth, BMI and their percentiles, as well as \%FM, muscle tissue and body water content $(p>0.05)$. Likewise, there were no differences in SBP, DBP, MAP, body weight, height, BMI, \%FM, muscle tissue and body water content in children with asthma, recurrent infections, atopic dermatitis or allergic rhinitis (Mann-Whitney U Test, $p>0.05$ ).

Statistically significant correlations between SBP and DBP were observed. Body weight, $\mathrm{BMI}$ and \%FM were also statistically significant. A statistically significant negative correlation was found between muscle tissue content and muscle mass and $\% \mathrm{FM}$, regardless of gender. Body weight correlated negatively with muscle tissue, irrespective of gender (Spearman's rank correlation coefficient, $p<0.001$ ) (Table 3 ).

\section{Discussion}

Our study shows that insufficient recognition of HT in the pediatric population is a widespread problem. It is worth emphasizing that each participant was referred to the camp by a pediatrician, but no one was previously diagnosed with HT. Despite the recommendation to perform a BP measurement at every visit to the doctor, this test item seems to be overlooked. Another factor reducing the recognition of $\mathrm{HT}$ is the lack of constant BP values for the entire population of development age. The need to use percentile meshes may favor an incorrect assessment of the measurement result [10].

The effect of obesity on the increased incidence of HT among children and adolescents has been confirmed in numerous studies. Obese children show an increased resting heart rate and increased vascular resistance compared to their peers without obesity. In addition, the endocrine function of the adipose tissue, which promotes sympathetic stimulation and the renin-angiotensin-aldosterone system, enhances the retention of sodium and water [11].

The data obtained does not allow one to identify the type of HT in the subjects studied. However, a significant proportion of obese children in the HT group and no prior diagnosis of secondary HT results in the fact that the majority suffer from primary HT. It should be stressed, however, that each of the subjects with abnormal BP needs diagnostics that exclude the secondary causes of $\mathrm{HT}$, since only then is it possible to identify some of its primary character.

Given the aforementioned role of adipose tissue in HT pathophysiology, it could be assumed that an excessive amount of fat mass would have a significant advantage over BMI in terms of a positive correlation with BP. However, the obtained results have shown a similar accuracy of these parameters to identify individuals at risk for HT development. Perhaps the determination of \%FM would be useful in patients with well-developed muscle tissue, which may increase BMI. However, this study wasn't able to prove this statement, most likely because the analyzed group didn't contain children with extraordinary developed muscle tissue.

The higher values of BMI and body weight and the lower growth of the analyzed group of children against the background of the nationwide population may be due to the origin of the respondents from the countryside. According to US research, obesity among adults is more common in rural settings [12]. It has also been observed that children from rural areas were more likely to eat highly processed food and perform less physical activity [13]. Studies showing that children from cities are both taller and heavier than their peers in rural areas come mostly from developing countries [14]. Taking into consideration the fact that Poland is already classified as a highly-developed country, it is necessary to ask whether the lower growth of children from rural areas can also correspond to poor or inadequate nutrition. It should also be considered that the low growth in our population may be affected by chronic diseases such as bronchial asthma.

$\mathrm{BMI}$ expressed in the form of percentiles is widely used in the pediatric population. The main disadvantage of using BMI is the inability to evaluate body fat mass. This may lead to the qualification of a child with a high body mass but with low body fat as an overweight or obese child. Bioelectric impedance analysis is a safe and non-invasive method to determine the percentage of body fat content [15]. Using the differences in tissue resistance to current conductivity, fat-free mass and fat mass are determined [16]. With this method, we can distinguish many variables that may interfere with the measurement results. One of them is the state of hydration of the patient. Dehydration can increase overall tissue resistance and, consequently, affect the overestimation of FM in the patient [17]. Another variable is the level of filling of the stomach during the test. After eating a meal, the measured FM may seem lower than it actually is, and this state can last 2 to 4 hours [18]. Intensive physical exercise prior to the test may also affect fat-free mass and fat mass by overstating the first value and lowering the second [19].

Some children, while taking part in our study, were subject to chronic pharmacotherapy. Most of them made use of chronic bronchial asthma therapy (iGCS, MDIs and Montelucast) and chronic treatment for allergic rhinitis (antihistamine drugs). We saw no actual difference in growth between children treated in the iGCS and healthy children; however, the latest studies have 
shown their adverse effect on growth and bone development [20]. All asthmatics met the criteria for well-controlled asthma, using a maximum of 2 degrees of treatment according to GINA 2016, which means they were taking iGCS in small doses. MDIs are a group of drugs with potential side effects, such as tremors, headaches and sleeplessness [21]. Antihistamines may also affect cardiovascular functioning, as well as weight gain due to increased appetite [22]. However, the obtained results did not show this impact.

\section{Limitations of the study}

The largest limitation of our research was that \%FM does not include the distribution of adipose tissue and its excessive deposition in the central part of the body (visceral obesity), which has a more significant effect on BP [23]. The device we used wasn't designed to estimate the visceral fat level in pediatric patients. Therefore, we decided to compare \%FM effec- tivity in diagnosing obesity with BMI rather than the waist-hip ratio index, which is more appropriate for distinguishing visceral obesity. It is worth emphasizing that the obesity cut-off values proposed by the device software were estimated in reference to the Caucasian pediatric population and were done in England [9], and these may not be perfectly accurate for the Polish population.

\section{Conclusions}

There is a problem of under-diagnosis of HT in the pediatric population. Obesity and overweight are risk factors for abnormal BP. The strong correlation between excess FM and high BP makes BIA useful in patient selection in terms of the risk of diseases associated with obesity. Relating to these findings, body composition analyzers can be recommended as a non-invasive and reliable tool in a family practitioner's office.

Source of funding: This work was funded by the authors' resources. Conflict of interest: The authors declare no conflict of interests.

\section{References}

1. Kawalec W, Grenda R, Ziółkowska H, et al. Pediatria. Warszawa: Wydawnictwo Lekarskie PZWL; 2013 (in Polish).

2. Litwin M, Niemirska A. Nadciśnienie tętnicze pierwotne i zaburzenia metaboliczne u dzieci i młodzieży. Forum Zaburzeń Metabolicznych 2011; 2(2): 124-131 (in Polish).

3. Małecka-Tendera E, Socha P. Otyłość u dzieci i młodzieży. Warszawa: Wydawnictwo Lekarskie PZWL; 2011: 16-25 (in Polish).

4. Mikoś M, Mikoś M, Mikoś H, et al. Nadwaga i otyłość u dzieci i młodzieży. Now Lek 2010; 79(5): 397-402 (in Polish).

5. Kucharska A, Burakowska I, Wronka L, et al. Body composition and blood lipid profile in patients with hypertension. Pielęg Pol 2016; 59(1): 61-65.

6. Pirogowicz I, Ornat M, Pachołek K, et al. The influence of physiotherapy on blood pressure in children and adolescents with respiratory tract diseases. Fam Med Prim Care Rev 2017; 19(1): 54-58.

7. Falkner B, Daniels SR, Flynn JT, et al. The fourth report on the diagnosis, evaluation, and treatment of high blood pressure in children and adolescents. Pediatrics 2004; 114: 555-557.

8. Kułaga Z, Litwin M, Tkaczyk M, et al. Polish 2010 growth references for school-aged children and adolescents. Eur J Pediatr 2011; 170(5): 599-609.

9. McCarthy HD, Cole TJ, Fry T, et al. Body fat reference curves for children. Int J Obes 2006; 30(4): 598-602.

10. Kaelber DC, Liu W, Rosset M, et al. Diagnosis and medication treatment of pediatric hypertension: a retrospective cohort study. Pediatrics 2016; 138(6): pii: e20162195.

11. Sorof J, Daniels S. Obesity hypertension in children. Hypertension 2002; 40(4): 441-447.

12. Befort CA, Nazir N, Perri MG. Prevalence of obesity among adults from rural and urban areas of the United States: findings from NHANES (2005-2008). J Rural Health 2012; 28(4): 392-397.

13. Davis A, Boles R, James R, et al. Health behaviors and weight status among urban and rural children. Rural Remote Health 2008; 8(2): 810.

14. Fox K, Heaton TB. Child nutritional status by rural/urban residence: a cross-national analysis. J Rural Health 2012; 28(4): 380-391.

15. Płaczkowska S, Pawlik-Sobecka L, Kokot I, et al. Wykorzystanie bezpośrednich i pośrednich metod oceny profilu składu ciała u młodych osób - badanie pilotażowe. Fam Med Prim Care Rev 2015; 17(1): 33-38 (in Polish).

16. Khalil SF, Mas SM, Fatimah I. The theory and fundamentals of bioimpedance analysis in clinical status monitoring and diagnosis of diseases. Sensors 2014; 14(6): 10895-10928.

17. Lukaski HC, Bolonchuk WW, Hall CB, et al. Validation of tetrapolar bioelectrical impedance method to assess human body composition. J Appl Physiol 1986; 60(4): 1327-1332

18. Mialich MS, Faccioli-Sicchieri JM, Jordao AA. Analysis of body composition: a critical review of the use of bioelectrical impedance analysis. International Journal of Clinical Nutrition 2014; 2(1): 1-10.

19. Abu Khaled M, McCutcheon MJ, Reddy S, et al. Electrical impedance in assessing human body composition: the BIA method. Am J Clin Nutr 1988; 47(5): 789-792.

20. Skoner DP. Inhaled corticosteroids: effects on growth and bone health. Ann Allergy Asthma Immunol 2016; 117(6): 595-600.

21. Sadhasivam NB. Adverse drug reaction of anti-asthmatic drugs prescribed in asthma out-patient department in a tertiary care hospital. University Journal of Pre and Paraclinical Sciences 2016; 2(3)

22. Ossi S, ed. Australian medicines handbook 2014. Adelaide: Australian Medicines Handbook Pty Ltd; 2014.

23. Gutiérrez Hervás A, Rizo Baeza MM, Martínez Amorós N, et al. Systolic pressure, abdominal obesity and body fat, metabolic syndrome predictors in Spanish preschoolers. Nutr Hosp 2014; 31(5): 2109-2114.

Tables: 3

Figures: 5

References: 23

Received: 22.04.2017

Revised: 23.05.2017

Accepted: 24.05.2017
Address for correspondence:

Iwona Pirogowicz, MD, PhD

Katedra i Klinika Geriatrii UM

ul. M. Skłodowskiej-Curie 66

50-369 Wrocław

Polska

Tel.: +48 71 784-25-21

E-mail: iwona.pirogowicz@umed.wroc.pl 